\title{
ZMIANY DEMOGRAFICZNE JAKO ZAGROŻENIE DLA BEZPIECZEŃSTWA. ANALIZA NA PRZYKLADZIE JAPONII
}

\begin{abstract}
„Istnieje ogromna siła, która jest w stanie zaszkodzić dzisiejszym potęgom przez dziesiątkowanie ich sił zbrojnych, paraliżowanie ich ekonomii i zmianę tła politycznego. Ta siła to nie nowy typ broni, nowa taktyka czy środek chemiczny lub biologiczny. To coś o wiele bardziej powolnego i zagadkowego: starzenie się społeczeństwa”.
\end{abstract}

(Sciubba, 2011: 1)

Zmiany demograficzne stają się coraz większym wyzwaniem dla rządów i gospodarek większości państw rozwiniętych. Możliwość analizy i prognostyki zmian w strukturach demograficznych znacząco wpływa na bezpieczeństwo państwa, zwłaszcza w kontekście bezpieczeństwa militarnego oraz ekonomicznego, dlatego nie bez przyczyny problematyka demografii zajmuje dziś coraz ważniejszą pozycję w programach rządów. Zmiany struktury populacji w dużym stopniu decydują bowiem o bezpieczeństwie państwa pod względem zasobów ludzkich i stabilności gospodarczej. Głównymi problemami gospodarek azjatyckich - związanymi z demografią - są z jednej strony starzenie się społeczeństwa i niski przyrost naturalny, a z drugiej strony eksplozja demograficzna. Zjawiska te z kolei kształtują możliwości polityczne, ekonomiczne i militarne, wpływając na międzynarodowy status poszczególnych państw i, co za tym idzie, bezpieczeństwo globalne. Wszystkie wymienione kwestie wymuszają zastosowanie adekwatnej strategii zmian strukturalnych w sferze ekonomicznej i społecznej, gdyż stało się jasne, że trendy demograficzne mają bezpośredni wpływ na wzrost gospodarczy, skalę ubóstwa, opiekę społeczną i udział państwa w polityce międzynarodowej.

\section{ZARYS PROBLEMATYKI PRZEMIAN DEMOGRAFICZNYCH W JAPONII}

Z punktu widzenia badań demograficznych, szczególnie ciekawym przykładem jest Japonia, gdzie obserwujemy bezprecedensową kumulację różnych zjawisk demograficznych. To, co budzi obawę japońskich badaczy, to przede wszystkim fakt, że japońskie społeczeństwo starzeje się najszybciej na świecie, a ponadto w najbliższych dekadach będzie się równie szybko kurczyć. Dodatkowym aspektem inicjującym zmiany w strukturze japońskiej populacji jest migracja ludności, przy czym ze względu na restrykcyjną międzynarodową politykę migracyjną Japonii obserwujemy głównie zmiany związane z migracją wewnętrzną z obszarów wiejskich do obszarów zurbani- 
zowanych. Skala tych trzech zjawisk: starzejącego się społeczeństwa, niskiej liczby urodzeń i migracji wewnętrznej jest na tyle zaawansowana, że w ostatniej dekadzie programy każdych kolejnych rządów wyznaczane były w dużej mierze przez te trendy demograficzne.

Demografowie zapowiadają w kolejnych dekadach spadek liczby urodzeń w większości państw rozwiniętych. W latach 50. ubiegłego stulecia populacja Ameryki Północnej, Europy i Japonii stanowiła blisko jedną trzecią światowej populacji. Do roku 2050 ludność tych państw będzie stanowiła już tylko jedną siódmą światowej populacji (Leuprecht, 2010: 29-30). Spadek liczby ludności jest bezpośrednim skutkiem niskiego współczynnika dzietności ${ }^{1}$ (ang. total fertility rate). Dziś już tylko 3\% światowej populacji zamieszkuje państwa, w których współczynnik dzietności nie spada (Demography is destiny, 2012). Wśród państw Azji Wschodniej Japonia zaczęła doświadczać tego problemu jako pierwsza. W analizie cyklu zmian związanych z dzietnością warto nakreślić ogólne trendy demograficzne w Japonii w ciagu ostatnich dekad. Badacze japońskiej demografii, R. Retherford i N. Ogawa, dzielą powojenny cykl zmian dzietności na trzy etapy: 1) 1947-1957², kiedy współczynnik dzietności w Japonii zmniejszył się o ponad połowę; 2) 1957-1973, kiedy współczynnik dzietności się ustabilizował; 3) od 1973 do dnia dzisiejszego, kiedy współczynnik dzietności ponownie zaczął spadać, inicjując niekończący się niż demograficzny (Retherford, Ogawa, 2005: 1).

Spadek liczby narodzonych dzieci $\mathrm{w}$ okresie powojennym spowodowany był głównie trudną sytuacją kraju, który dopiero co otrząsał się z dramatycznych wydarzeń II wojny światowej. Nie bez znaczenia dla spadku dzietności była również legalizacja aborcji w 1948 r. Drugi etap obejmuje okres japońskiego wzrostu gospodarczego i jednocześnie stanowi lata stabilizacji liczby urodzeń. Stabilizacja ta oznaczała, że współczynnik dzietności przekraczał w tym czasie tzw. próg zastępowalności ${ }^{3}$. W tym okresie wynosił niemalże nieprzerwanie około 2,1. Jednakże kryzys naftowy lat 70 . XX w., a w konsekwencji recesja gospodarcza Japonii i galopująca inflacja ponownie wpłynęły na liczbę narodzin w tym okresie (ibidem: 2). Począwszy od 1973 r. odsetek narodzin wykazuje tendencję spadkową i podczas gdy w 1973 r. współczynnik dzietności wynosił 2,14, w 2005 r. spadł do 1,26, co stanowiło najniższy wynik w historii Japonii. Statystyki wykazują, iż od 2005 roku współczynnik nie przejawia znaczących tendencji spadkowych, ale mimo jednoczesnego wzrostu umieralności wśród stale rosnącej grupy osób starszych, próg zastępowalności wydaje się być w tym momencie nieosiagalny (,Asahi Shimbun”, 2014).

\footnotetext{
1 Współczynnik dzietności jest wyznaczany poprzez liczbę dzieci przypadających na jedną kobietę w wieku rozrodczym.

Autorzy nie uwzględniają bardzo krótkiego wyżu demograficznego w 1. 1947-1949, podczas którego na świat przyszło ponad 8 milionów dzieci. Osoby urodzone w tych latach weszły w wiek emerytalny ok. 2007 r. W tym czasie zaczęto mówić o „problemie 2007 r.”, czyli o konsekwencjach przejścia na emeryturę osób urodzonych podczas wyżu demograficznego dla sytuacji ekonomicznej kraju. Więcej na ten temat: Baby boom sets Japan '2007 problem', http://news.bbc.co.uk/2/hi/ asia-pacific/5263514.stm (4.12.2014).

3 Próg zastępowalności jest osiagnięty wówczas, kiedy na jedną kobietę (oraz jej partnera) przypada co najmniej dwójka dzieci. Z uwagi na fakt, że część urodzonych dzieci nie dożyje wieku produkcyjnego, próg zastępowalności wynosi 2,1.
} 
Bezpośrednim skutkiem niskiego współczynnika dzietności (a przy tym nieosiaganie progu zastępowalności) jest starzenie się społeczeństwa (ang. aging of population). Zjawiskiem starzenia się społeczeństwa nazywamy proces ,względnego wzrostu liczby ludności w wieku starszym (np. powyżej 60 lat)” spowodowanego „długotrwałym spadkiem natężenia zgonów, a zwłaszcza zmniejszeniem natężenia urodzeń” (Holzer, 2013: 16). Japońskie społeczeństwo jest najstarszym na świecie - w 2010 r. ponad połowę populacji stanowiły osoby w wieku ponad 45 lat, a - jak podają raporty statystyczne ONZ - do 2050 r. średni wiek populacji wyniesie 53 lata (World Population Aging 2013, 2013: 20-21). Dla porównania, te same statystyki podają średnią wieku w gospodarkach wysoko rozwiniętych, która wynosiła 40 lat w $2010 \mathrm{r}$. i będzie wynosiła 44 lata w 2050 r. Ponieważ problem starzejącego się społeczeństwa dotyka głównie państwa o wysokim poziomie rozwoju gospodarczym, warto przybliżyć te same dane statystyczne biorąc pod uwagę średnią światową. Średni wiek całej światowej populacji wynosi odpowiednio: 29 lat w 2010 r. i 36 lat w 2050 r. (ibidem). Co więcej, na przestrzeni zaledwie 24 lat (1970-1994), odsetek osób starszych ${ }^{4}$ wzrósł w Japonii dwukrotnie z 7 do 14\%. Analogicznie, wśród starzejących się społeczeństw krajów europejskich (Niemcy, Hiszpania, Finlandia itd.) tak duży wzrost liczby osób starszych trwa ok. 40 lat, a w państwach o stosunkowo powolnym procesie starzenia się społeczeństwa - ok. 100 lat (International Longevity Center Japan, [bez daty]: 1). Jak pokazują dane (wykres 1), liczba osób zarówno w grupach do 14 roku życia, jak i osób w wieku

Wykres 1. Zmiany populacji z podziałem na grupy wiekowe (mln)

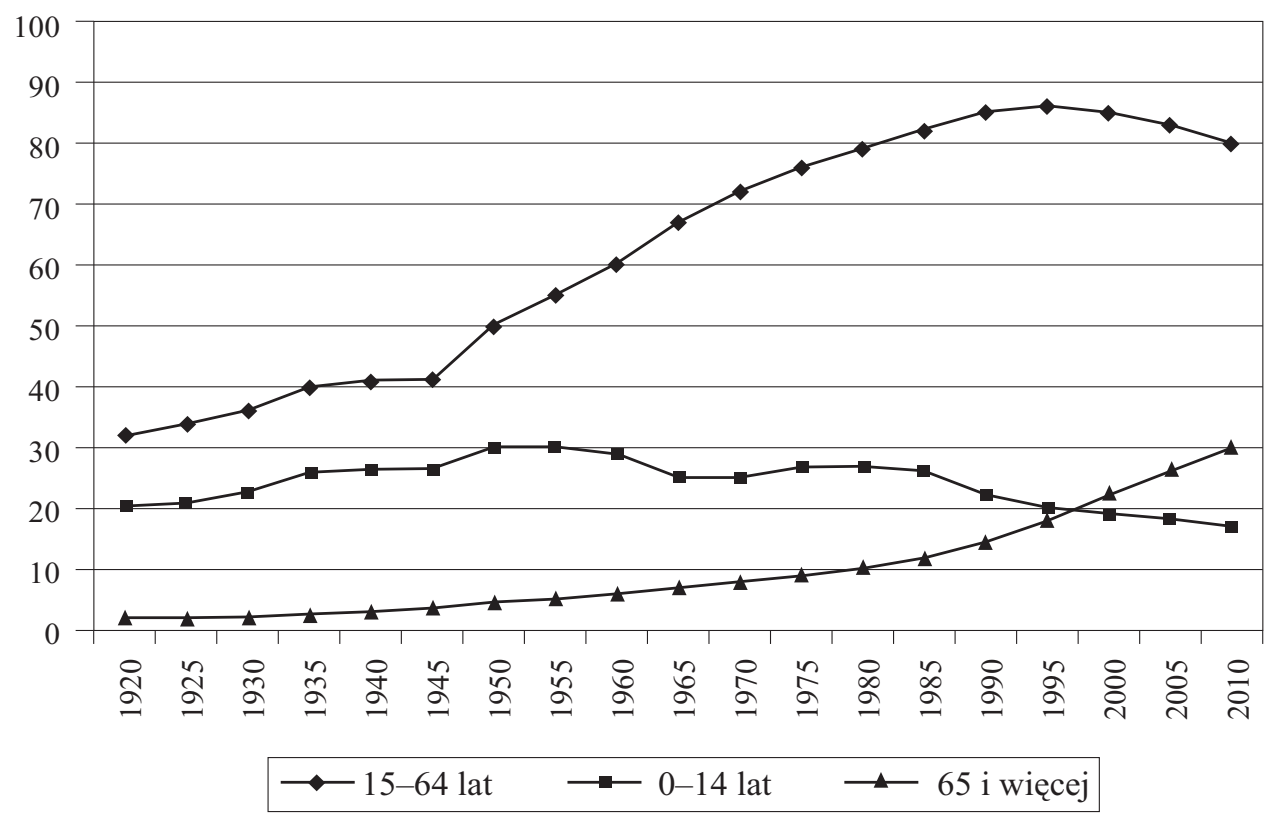

Źródło: Japan in figures and graphs (2011), Official Statistics of Japan, http://e-stat.go.jp/SG1/estat/ GL36010101.do?_toGL36010101_(4.12.2014).

4 Tu: osoby powyżej 65. roku życia. 
od 15 do 64 lat maleje. Osoby starsze znajdujące się jeszcze w grupie wiekowej do 64 lat sukcesywnie zasilają najstarszą grupę wiekową, co z kolei przyczyniło się do wzrostu populacji osób z najstarszej grupy wiekowej do $30 \mathrm{mln}$ w $2010 \mathrm{r}$.

Przyczyną powiększania się grupy osób starszych jest ponadto wydłużenie się średniej długości życia. Podniesienie standardów życia, postęp medycyny i rozwój opieki społecznej sprawiły, że długość życia stale się wydłuża. Jak pokazują raporty Światowej Organizacji Zdrowia, Japonia zajmuje pierwsze miejsce pod względem średniej długości życia, która wynosi 84 lata uwzględniając obie płcie ${ }^{5}$ (World Health Organization, 2014). Dla porównania, w Polsce średnia długość życia wynosi 77, a w USA 79 lat. Starzenie się społeczeństwa w Japonii jest najbardziej widoczne na obszarach wiejskich, gdzie dodatkowo odnotowuje się duży odpływ ludności w wieku produkcyj-

Wykres 2. Zmiany bilansu ludności z podziałem na obszary (\%)

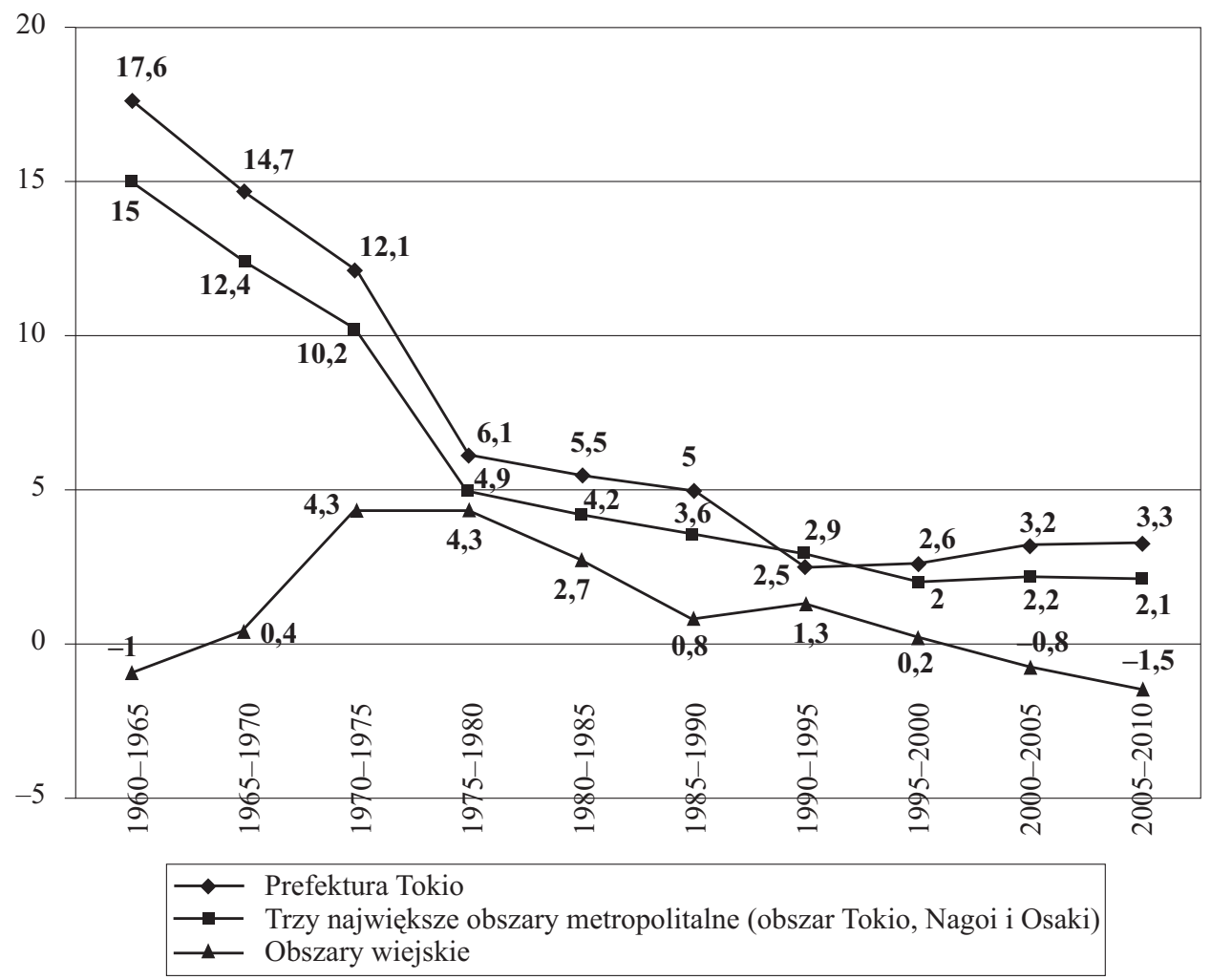

Źródło: Sōmushō [Ministerstwo Spraw Wewnętrznych i Komunikacji] (2012), Kaso taisaku no genkyō [Stan obecny strategii dla depopulacji], http://www.soumu.go.jp/main_content/000276127.pdf (5.12.2014).

5 Długość życia różni się w poszczególnych regionach Japonii. Najkrócej żyją mieszkańcy północno-wschodnich regionów, północnej części Kyūshū i części regionu Kansai. Najdłużej zaś żyją mieszkańcy wiejskich obszarów środkowej części Japonii i mieszkańcy Okinawy. Tu również współczynnik dzietności jest o wiele wyższy niż w całej Japonii. Więcej na temat demografii regionalnej: Lützeler R. (2008), Regional demographics, w: The demographic challenge: A handbook about Japan, (eds.) F. Coulmas, H. Conrad, A. Schad-Seifert, G. Vogt, Boston. 
nym do miast. Spadek liczby ludności na terenach wiejskich oznacza pojawiające się społeczne ograniczenia mieszkańców tych obszarów, a z drugiej strony migracja do terenów zurbanizowanych oznacza ich przeludnienie (Lützeler, 2008: 63). Nierównomierne zagęszczenie ludności, spowodowane w przypadku Japonii migracją wewnętrzną ze wsi do miast, jest efektem industrializacji kraju i pojawienia się szerokich możliwości zawodowych i edukacyjnych, jakie czekają na osoby w wieku produkcyjnym w miastach. Zgodnie z wyliczeniami Banku Światowego, już ponad 90\% ludności Japonii mieszka na terenach zurbanizowanych (World Bank, 2014). Ze względu na to, że migracja dotyczy głównie ludzi młodych, odsetek populacji w wieku rozrodczym na obszarach wiejskich gwałtownie spada. Jak zostało przedstawione powyżej (wykres 2), obszary te od drugiej połowy lat 90 . XX w. zmagają się z depopulacją.

\section{PRZYCZYNY ZMIAN DEMOGRAFICZNYCH}

W 2010 r. populacja Japonii była rekordowo wysoka i przekroczyła liczbę 128 milionów ludzi. Niski współczynnik dzietności sprawił jednak, że po roku 2010 liczba ludności zaczęła stopniowo spadać. Jak pokazują statystyki, do 2050 roku populacja Japonii skurczy się do ok. 100 milionów (Yashiro, 2008: 933). Zmienne w demografii są stosunkowo przewidywalne - krótko mówiąc, obecny obraz społeczeństwa w ogromnym stopniu przełoży się na trendy demograficzne w kolejnych dekadach. $\mathrm{Z}$ drugiej strony jednak, mimo wiarygodnych i długoterminowych prognoz, Japońscy badacze nie są wstanie osiągnąć konsensusu co do głównej przyczyny nadal ujemnego współczynnika dzietności (ibidem: 933). O ile bezpośrednimi przyczynami starzenia się społeczeństwa są - jak już wspomniano - niska liczba urodzeń, spadek natężenia zgonów i wydłużenie się średniej długości życia, to przyczyny spadku urodzeń są kwestią o wiele bardziej złożoną.

Struktura demograficzna Japonii wpisuje się w model nazywany przez teoretyków „drugim przejściem demograficznym”. Jak wskazuje polski badacz demografii, Jerzy Holzer, oznacza to, że w społeczeństwie można wyodrębnić następujące zjawiska: 1) opóźnianie wieku zawierania małżeństwa, osłabienie trwałości małżeństwa i wzrost liczby związków nieformalnych; 2) późniejsza decyzja o urodzeniu dziecka i przesunięcie się wieku maksymalnej płodności; 3) dostęp do antykoncepcji i świadome planowanie rodziny; oraz 4) zmiana trybu życia i spadek umieralności (Holzer, 2003: 24-25). Wszystkie powyższe elementy wpisują się w charakterystykę społeczeństwa japońskiego, a ich znajomość jest niezwykle istotna przy analizie przyczyn spadku dzietności. Natomiast, aby łatwiej było zidentyfikować z czego wynika niski współczynnik urodzeń, można rozpatrywać przyczyny w dwóch głównych kategoriach: związane z uwarunkowaniami zewnętrznymi (rozwój ekonomiczny, edukacja, udział kobiet w rynku pracy itd.) oraz związane z ewolucją przekonań i stylu życia (późne decyzje o posiadaniu dzieci, chęć kontynuowania kariery, model rodziny $2+1$ itd.).

Omawiając przyczyny związane $\mathrm{z}$ uwarunkowaniami zewnętrznymi, należałoby zaczać od sytuacji ekonomicznej, która w Japonii znacząco wpłynęła na przemiany demograficzne. Dekady cudu gospodarczego zbiegły się w czasie z liberalizacją prawa aborcyjnego oraz z rozpowszechnieniem się antykoncepcji. Przede wszystkim jednak, 
w latach powojennych zaczął wzrastać udział kobiet w rynku pracy i podczas gdy w 1950 r. 29\% kobiet pracowało w sektorach innych niż rolniczy, w 1970 r. odsetek ten wynosił już 37\% (Hashimoto, 1974: 226). Ponadto wzrosła całkowita proporcja liczby pracujących kobiet - dziś około 99\% kobiet ma doświadczenie zawodowe przed wstąieniem w stały związek, a zatem małżeństwo nie jest już absolutną koniecznością z uwagi na kwestie ekonomiczne (Matsukura, Retherford, Ogawa, 2007: 37). Rozwój gospodarczy $\mathrm{i}$ idąca za tym industrializacja stworzyły również nowe szanse dla zatrudnienia kobiet. Zmiany te mogą prowadzić do opóźniania decyzji o małżeństwie ${ }^{6}$ (lub zupełnej rezygnacji z małżeństwa) - kobiety chcą być niezależne finansowo i chcą osiagać coraz więcej w życiu zawodowym i osobistym. To z kolei przekłada się na ilość urodzeń, a należy nadmienić, że w Japonii tylko $2 \%$ dzieci rodzi się poza związkami małżeńskimi. Stanowi to wyraźny kontrast w porównaniu do USA (33\%) czy państw europejskich, wśród których rekordzistami są Szwecja (55\%) i Islandia (66\%) („The Economist", 2011). Zatem bazując na powyższych danych można wnioskować, że w społeczeństwie japońskim małżeństwo jest elementem koniecznym dla posiadania dzieci, ale wstąpienie w związek małżeński wcale nie gwarantuje wzrostu liczby urodzeń.

Sama aktywność kobiet na rynku pracy nie tłumaczy jednak tak drastycznego spadku dzietności ${ }^{7}$. Jednym z dodatkowych czynników jest tu dostęp do edukacji, który kobiety w Japonii uzyskały w wyniku powojennych reform. Badania wykazują, że edukacja jest jednym z najbardziej znaczących powodów niskiego współczynnika urodzeń. Kiedy odsetek kobiet posiadających średnie wykształcenie się podwaja, średnia liczba urodzeń spada o co najmniej jedno dziecko (Subbarao, 2011: 105-128). Osoby lepiej wykształcone bardziej kontrolują planowanie rodziny i mają mniej dzieci oraz planują większe wydatki na dziecko w celu zapewnienia mu określonych warunków bytowych. Rozwój ekonomiczny wiąże się również ze wzrostem cen dóbr i usług, a zatem koszty utrzymania rodziny są również wyższe, co tłumaczy spadek współczynnika dzietności w okresie japońskiego boomu gospodarczego. Badacze zauważają nawet, że globalizacja ekonomiczna i reformy zorientowane na politykę rynkową oznaczają spadek poczucia bezpieczeństwa w rodzinie (Matsukura, Retherford, Ogawa, 2007: 39). Zjawisko to jest szczególnie wyraźne w Japonii, ponieważ duża część gospodarki opiera się właśnie na handlu zagranicznym. Znajduje to swoje odzwierciedlenie w zapewnieniu możliwości zawodowych - podczas gdy konkurencja na rynku pracy wzrasta, stabilność pracy spada ${ }^{8}$. Ogromne znaczenie ma tu długotrwała stagnacja i kolejne kryzysy ekonomiczne. Biorąc zatem pod uwagę niepewną karierę swojego partnera wiele kobiet uznaje pracę zarobkową za konieczną (ibidem).

Kolejnym elementem wpływającym na decyzję o posiadaniu dzieci jest system japońskiej opieki społecznej. Jak oceniają obserwatorzy, mimo że oficjalnie urlopy ma-

${ }^{6}$ Od 2006 r. najwięcej dzieci rodzą kobiety znajdujące się w grupie wiekowej od 30-34 lat. Przed 2006 r. zdecydowana większość matek decydowała się na dzieci w wieku 25-29 lat (Ministerstwo Zdrowia, Pracy i Opieki Społecznej, 2011).

7 Wystarczy spojrzeć na badania przeprowadzone w Szwecji i Norwegii, gdzie mimo wysokiego odsetka pracujących kobiet współczynnik dzietności jest wyższy (Yashiro, 2008: 936).

8 Japońskie firmy stopniowo odchodzą od tradycyjnego modelu dożywotniego zatrudnienia. Obecnie taki model zatrudnienia zgłasza niewiele ponad 10\% przedsiębiorstw (Matsukura, Retherford, Ogawa, 2007: 39). 
cierzyńskie i wychowawcze są dość długie ${ }^{9}$, niekompletne regulacje prawne sprawiają, że nie dla wszystkich kobiet są one dostępne (Usui, 2008: 171). Wynika to z faktu, iż niektórzy pracodawcy patrzą nieprzychylnie na urlopy macierzyńskie. Firma może zadecydować o zmianie stanowiska lub miejsca pracy pracownicy, która wraca do pracy po urlopie macierzyńskim lub wychowawczym, skłaniając ją tym samym do dobrowolnej rezygnacji z pracy na rzecz wychowania dziecka („Asahi Shimbun”, 2005). Kobieta, która zwalnia się dobrowolnie, automatycznie traci przywileje gwarantowane przez opiekę społeczną ${ }^{10}$. O skali problemu może świadczyć odsetek kobiet, którym udaje się wrócić po urlopie macierzyńskim do pełnoetatowej pracy - wynosi on jedynie $46 \%$ (Reuters, 2014). Ponadto, osoby posiadające dzieci napotykają szereg dodatkowych problemów m.in. zbyt mała liczba autoryzowanych przez rząd placówek opiekuńczych (żłobków i przedszkoli). W najbardziej skrajnych przypadkach czas oczekiwania na miejsce w takim ośrodku wynosi kilka lat. Mimo że rząd premiera Abe dokłada starań do poprawy sytuacji, liczba placówek jest nadal zbyt mała. („,The Japan Times”, 2013). Można zatem mówić o braku bezpieczeństwa pracy dla matek po urlopach macierzyńskich i wychowawczych, co istotnie wpływa na decyzję o posiadaniu więcej niż jednego dziecka, lub o macierzyństwie w ogóle.

Bezpośrednio z powyższych uwarunkowań socjoekonomicznych wynikają zmiany w wartościach, przekonaniach i stylu życia młodych ludzi. Przede wszystkim spada liczba małżeństw, które mieszkają razem z rodzicami. Inwestycja we własne lokum jest dla wielu na tyle kosztowna, że rośnie liczba par preferujących wolne związki. Zmniejsza się również presja społeczna na osoby żyjące bez partnera, przez co coraz więcej jest osób wiodących samotne życie (Retherford, Ogawa, 2005: 9). Życie w wolnych związkach stało się dla młodych ludzi atrakcyjną alternatywą, a więc inwestycja w dzieci jest coraz częściej odkładana na dalszy plan.

\section{WPLYW ZMIAN DEMOGRAFICZNYCH NA BEZPIECZEŃSTWO}

Łagodzenie skutków zmian demograficznych - w przypadku Japonii głównie problemu starzejącego się społeczeństwa i niskiego współczynnika dzietności-jest strategicznym wyzwaniem dla władz państwa. Strategia ta jest bardzo złożona, musi się bowiem koncentrować na wielu płaszczyznach jednocześnie: ekonomicznej, socjalnej i politycznej. Jak zauważają badacze, środowisko bezpieczeństwa jest zupełnie inne niż dekadę czy dwie dekady temu. Pojawiają się nowe potęgi gospodarcze, mamy dostęp do coraz bardziej zaawansowanej technologii, zwiększa się również konieczność szybkiego reagowania w razie konfliktu (Sciubba, 2011: 1-2). Państwo potrzebuje za-

9 Urlop macierzyński trwa 14 tygodni, a rodzic dostaje zasiłek w wysokości ok. 67\% miesięcznego wynagrodzenia.

10 Sytuacja kobiet w miejscu pracy, zwłaszcza tych, które decydują się na macierzyństwo, wykracza poza spektrum niniejszego artykułu. Niemniej jednak, ogólne uwarunkowania społeczne i kulturowe są niezbędne do bliższej analizy przyczyn niskiego współczynnika urodzeń. Szerzej na ten temat w: Usui C. (2008), Ageing Society and the Transformation of Work in the Post-Fordist Economy, w: The demographic challenge: A handbook about Japan, (eds.) F. Coulmas, H. Conrad, A. Schad-Seifert, G. Vogt, Boston. 
równo obrony przed zagrożeniem zewnętrznym, jak i szeregu działań zapobiegających utracie stabilności wewnętrznej. Podczas gdy środowisko międzynarodowe wymaga od Japonii coraz większej inicjatywy w zobowiązaniach militarnych, zmiany demograficzne zaczynają stanowić problem w utrzymaniu równowagi wewnętrznej kraju. Stabilność ta powinna się bowiem opierać m.in. na dostatecznych zapleczach siły militarnej i roboczej oraz stałych źródłach finansowania tychże elementów.

Konsekwencje, jakie niesie za sobą niski współczynnik dzietności, można rozpatrywać w dwóch perspektywach. W skali makro - zbyt niska liczba urodzeń powoduje spadek liczby osób w wieku produkcyjnym. To z kolei prowadzi do ograniczania inwestycji i konsumpcji, a w dłuższej perspektywie przyczynia się do stagnacji ekonomicznej. Jednocześnie wzrastają wydatki państwa na opiekę społeczną. W ujęciu mikro mamy zaś do czynienia z przeludnieniem terenów zurbanizowanych i depopulacją obszarów wiejskich. Jednym z głównych pytań, jakie według N. Ogawy zadaje sobie dziś rząd Japonii, jest to czy i w jaki sposób uda się Japonii utrzymać wzrost ekonomiczny ze starzejącą się siłą roboczą i kurczącą się populacją (Ogawa, 2008: 823). Idąc tym tropem można (i trzeba) zapytać, w jaki sposób Japonia chce zapewnić bezpieczeństwo państwa w czasie, gdy demografia przyczynia się do stagnacji ekonomicznej, do budżetu państwa wpływa coraz mniej funduszy, a niski współczynnik urodzeń sprawia, że zmniejsza się liczba potencjalnych chętnych do wstapienia do sił zbrojnych. Wzrasta natomiast potrzeba zapewnienia bazy militarnej i przemysłowej.

Jak podsumowują obserwatorzy, ,demografia wpływa na potęgę państwa poprzez zasoby ludzkie i wzrost ekonomiczny" (Sciubba, 2011: 4). Właśnie te dwie perspektywy, populacyjna i ekonomiczna, będą stanowić podstawę do określenia wpływu zmian demograficznych na bezpieczeństwo państwa. Po pierwsze, zasoby ludzkie to przede wszystkim siła robocza. Populacja osób w wieku produkcyjnym przyczynia się do wzrostu gospodarczego, a warto zaznaczyć, że to właśnie powojenny wzrost gospodarczy pozwolił Japonii zwiększyć swoje wpływy i niezwykle umocnić pozycję na arenie międzynarodowej (ibidem: 65). Tak jak wzrost gospodarczy wzmocnił pozycję Japonii po II wojnie światowej, tak teraz długoletnia stagnacja ekonomiczna poparta problemami demograficznymi może $\mathrm{w}$ dłuższej perspektywie doprowadzić do marginalizacji państwa. Wystarczy spojrzeć na wpływ stagnacji ekonomicznej Japonii na aktywność kraju w działaniach międzynarodowych - w latach 1990-2000 Japonia była największym państwem-dawcą oficjalnej pomocy rozwojowej wśród państw wysokorozwiniętych. Jednak na skutek ograniczeń finansowych spowodowanych spowolnieniem gospodarki, dziś Japonia znajduje się na piątym miejscu wśród krajów-dawców (Atanassova-Cornelis, 2010: 409). Dodatkowo pojawia się pytanie, czy w związku z recesją Japonia będzie w stanie wywiązać się ze swoich zobowiązań wobec środowiska międzynarodowego. Od początku lat 90. XX w. japońskie Siły Samoobrony angażują się w misje pokojowe ONZ zgodnie z wprowadzonym w 1992 roku prawem dotyczącym Operacji Wsparcia Pokoju Międzynarodowego (ang. International Peace Cooperation Law). Do tej pory Japonia wysłała kadry Sił Samoobrony na operacje pokojowe m.in. w Kambodży, Mozambiku, Sudanie i Timorze Wschodnim oraz brała udział w akcjach humanitarnych w Rwandzie, Afganistanie i Iraku, a wkład finansowy Japonii stanowi ok. 11\% budżetu ONZ przeznaczanego na operacje pokojowe (Gaimushō, 2014). Co więcej, Japonia zwiększa nie tylko swoje zobowiązania, ale również swoje aspiracje 
- przykładem może być wieloletnie ubieganie się Japonii o stałe członkostwo w Radzie Bezpieczeństwa ONZ. Do tej pory największą przeszkodą na drodze do stałego członkostwa Japonii jest sprzeciw ChRL („Asahi Shimbun”, 2014). Jeżeli jednak Japonii udałoby się znaleźć w RB, niewątpliwie miałoby to dla państwa ogromne znaczenie strategiczne $^{11}$.

Warto się również przyjrzeć, w jaki sposób kondycja ekonomiczna Japonii przekłada się na jej działania w regionie. Przykładem może być konkurowanie Japonii i Chin o kwotę dotacji podczas negocjacji dotyczących regionalnego porozumienia finansowego, Inicjatywy Chiang Mai, w 2009 r. Negocjacje były wówczas przedłużane do momentu, w którym obie strony zgodziły się na przekazanie tej samej kwoty na rzecz porozumienia (Terada, Ong, 2011: 210-211). Kolejnym przykładem są kwoty, jakie Japonia przekazuje na międzynarodowe instytucje finansowe takie, jak np. Międzynarodowy Fundusz Walutowy (IMF) czy Azjatycki Bank Rozwoju (ADB). W instytucjach tych Japonia nadal wyprzedza Chiny. Liczba głosów ${ }^{12}$, jaką dysponuje Japonia w IMF wynosi 6,23\%, ChRL natomiast 3,81\% (Międzynarodowy Fundusz Walutowy, 2014). W ADB dotacje finansowe z Japonii przekroczyły natomiast $100 \mathrm{mln}$ dolarów, co stanowi 9\% ogólnej sumy dotacji wszystkich państw członkowskich (Asian, 2013: 34). Środki finansowe przekazywane przez Japonię na wszelkiego rodzaju instytucje międzynarodowe są zatem nadal spore. Jednakże zestawiając ze sobą rosnącą potęgę ChRL i znajdującą się w recesji gospodarkę Japonii należy się zastanowić, czy i kiedy Japonia będzie zmuszona zmniejszyć swoje hojne finansowanie międzynarodowych inicjatyw. Biorąc pod uwagę wszystkie powyższe zobowiązania i aspiracje nasuwają się więc bardzo istotne pytania: do jakiego stopnia Japonia będzie nadal mogła aktywnie angażować się w bezpieczeństwo międzynarodowe i wspierać akcje pokojowe? Czy rząd będzie w stanie zrealizować swoje aspiracje i znaleźć rezerwy finansowe i personalne w państwie, które od lat zmaga się z recesją i z kurczącym się społeczeństwem?

Zasoby ludzkie, prócz omówionej wyżej siły roboczej, to również liczba osób mogących zasilić siły zbrojne państwa. Liczba ta na skutek starzenia się społeczeństwa będzie malała. W Japonii przewiduje się znaczący spadek liczby potencjalnych rekrutów już w ciągu następnej dekady (wykres 3). W 2000 r. liczba osób w wieku 19-45 lat wynosiła ponad $42 \mathrm{mln}$. Szacuje się, że do $2040 \mathrm{r}$. liczba ta spadnie o ponad $30 \%$. Dla porównania, w roku 2040 osoby powyżej 60. roku życia będą stanowiły niemal $50 \mathrm{mln}$, czyli ponad 40\% całej prognozowanej populacji Japonii (ONZ, 2014).

Ze strategicznego punktu widzenia, zasoby ludzkie są nieodzownym elementem siły militarnej kraju. Gdy zasoby te zaczynają się kurczyć, rząd musi dołożyć starań, aby wypracować inne sposoby poprawy sytuacji militarnej i przed takim dylematem stają również władze Japonii. Jednym z nich może być wdrażanie nowych, zaawansowanych technologii, które do pewnego stopnia mogą rekompensować braki zasobów ludzkich, np. roboty wykonujące niebezpieczne zadania, systemy precyzyjnego rażenia czy maszyny bezzałogowe (Sciubba, 2008: 46). Jednakże w tym przypadku powra-

11 Wielu obserwatorów odnosi się z dużą dozą sceptycyzmu co do stałego członkostwa Japonii w Radzie Bezpieczeństwa ONZ. Więcej na ten temat: Katsuno M. (2012), Japan 's Quest for a Permament Seat, http://library.fes.de/pdf-files/id/09024.pdf (4.12.2014).

12 Liczba głosów jest odzwierciedleniem kwoty udziałowej danego kraju. 
Wykres 3. Liczba osób w wieku 19-45 lat i 60+ (mln)

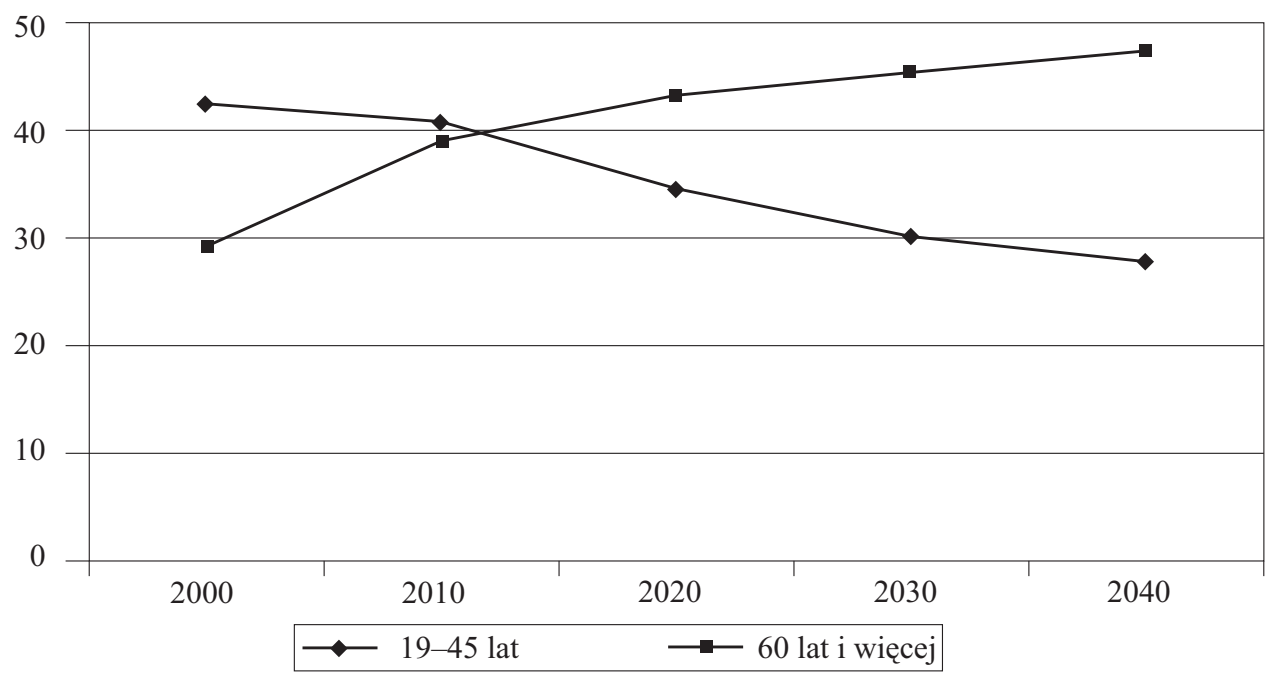

Źródło: Opracowanie własne na podstawie danych ONZ: United Nations, Department of Economic and Social Affairs, Population Division (2012), World Population Prospects: The 2012 Revision, http://esa.un.org/wpp/ unpp/p2k0data.asp (5.12.2014).

ca problem finansowania tychże technologii - w starzejących się społeczeństwach skala przedsiębiorczości i innowacyjności spada, a w konsekwencji przysparza dodatkowych trudności w powiększaniu PKB kraju (Chwiej, 2013: 142). Istnieje również możliwość zwiększenia wydajności sił zbrojnych, np. poprzez reorganizację na poziomie personelu i infrastruktury, co pozwoliłoby na zmniejszenie budżetu przeznaczanego na utrzymanie sił zbrojnych, a tym samym stanowiłoby oszczędność dla kraju w czasie stagnacji ekonomicznej. W Japonii ta opcja brana jest pod uwagę, co zresztą potwierdza bardzo wysoki poziom technologicznego zaawansowania, jaki prezentują Siły Samoobrony (Kingston, 2013: 120-121). Inną możliwością jest zawieranie i umacnianie sojuszy z państwami, których struktura demograficzna jest nadal stabilna, w celu ochrony wspólnych interesów ${ }^{13}$. W tej sytuacji w razie wystapienia jakiegokolwiek stanu zagrożenia, pomoc ze strony kraju sojuszniczego może być pewnego rodzaju rekompensatą dla ograniczonych liczebnie sił zbrojnych (ibidem: 48-50).

Finansowanie budżetu obronnego uzależnione jest od wpływu zjawiska starzejącego się społeczeństwa na ogólną kondycję gospodarki (ibidem: 52). Pod kątem ekonomicznym zjawisko to powoduje obciążenie budżetu państwa wydatkami na opiekę społeczną i mniejsze możliwości finansowania innych sektorów. Średnia długość życia w Japonii się wydłuża, a zatem osoby starsze często wymagają długotrwałej opieki i świadczeń socjalnych (personel opiekuńczy, sprzęt rehabilitacyjny, ubezpieczenia społeczne, emerytury itp.). Obecny japoński system podatkowy nie jest wystarczająco

13 Przykładem może być kandydatura Turcji na członka Unii Europejskiej. Współczynnik dzietności w Turcji przekracza próg zastępowalności i będzie powoli wzrastał. Stanowi to dużą szansę dla starzejącej się populacji Unii Europejskiej (więcej na ten temat: Sciubba, 2008: 48). 
efektywny by finansować rosnące potrzeby starzejącego się społeczeństwa, co zresztą było jednym z powodów wprowadzenia podatku konsumpcyjnego i podniesienia go do 8\% w 2014 r. (Kawase, Ogura, 2008: 853). Skalę problemu przybliża statystyka liczby osób pracujących na utrzymanie jednej osoby na emeryturze: w 1973 r. na jednego emeryta przypadało ok. 8 osób, w 2000 r. 3,6, a w 2020 r. na jednego emeryta będą pracowały tylko dwie osoby (ibidem: 843). Przeznaczanie coraz większej części budżetu na opiekę społeczną zdaje się nieuniknione. Istnieje zatem zagrożenie, że mniej środków finansowych będzie przyznawanych na siły zbrojne i obronę kraju (Sciubba, 2011: 55). Natomiast przy mniejszych nakładach pieniężnych wyszkolenie i wyposażenie sił zbrojnych może okazać się dla kraju poważnym wyzwaniem ${ }^{14}$. W takiej sytuacji znalazła się już część państw europejskich. Przykładem są trwające już od kilku lat cięcia w budżecie obronnym Francji (,The Telegraph”, 2014) lub plany budżetowe Wielkiej Brytanii, przewidujące zmniejszenie liczebności regularnej armii o 20\% do roku 2018 (BBC, 2014).

Zmiany demograficzne są również efektem migracji. Badania nad migracją wymagają szczególnej uwagi ze względu na to, że są najtrudniejsze do przewidzenia, a ich efekt jest widoczny w stosunkowo krótkim czasie (Sciubba, 2011: 84). Jak już wspomniano wcześniej, współczynnik migracji zewnętrznych jest całkowicie zależny od restrykcyjnej polityki migracyjnej Japonii. Dlatego też w tym przypadku mówimy raczej o skutkach braku imigracji. Za najbardziej znaczący efekt, możliwy do osiagnięcia poprzez zmianę polityki migracyjnej Japonii, uznaje się napływ osób w wieku produkcyjnym i rozrodczym, co z pewnością pozwoliłoby na poprawę struktury demograficznej w starzejącym się społeczeństwie japońskim. Jednak do konsensusu w sprawie prawa imigracyjnego daleko. Różne grupy interesu - związki zawodowe, przedsiębiorstwa itp. - prezentują różne stanowiska w tej kwestii. Obecnie, ze względów pragmatycznych, imigracja jest brana pod uwagę, lecz dotyczy jedynie pracowników wykwalifikowanych i tymczasowych. Jednakże ze względu na negatywne potencjalne skutki migracji, rząd japoński jest niechętny jakimkolwiek większym zmianom w tej kwestii, a premier otwarcie przyznaje, że nie popiera rozluźnienia polityki migracyjnej Japonii (,The Japan Times”, 2014).

W kontekście wpływu na ekonomię i bezpieczeństwo kraju, znacznie szerzej omawianym w Japonii typem migracji jest natomiast migracja wewnętrzna. Wzrost liczby migracji do obszarów zurbanizowanych powoduje depopulację obszarów wiejskich. Utrata osób w wieku produkcyjnym ma negatywny wpływ na zaplecze finansowe, ekonomiczne i społeczne miast i prefektur. $Z$ powodu małej ilości osób aktywnych zawodowo i powiększającego się odsetka osób starszych, budżety miast znajdujących się

14 Wbrew temu Japonia nadal przeznacza duże kwoty na budżet obronny. W 2014 r. japońskie Ministerstwo Obrony zawnioskowało o rekordową sumę ponad 47 mld dolarów z budżetu na $2015 \mathrm{r}$. Wynika to z założeń polityki premiera Shinzō Abe w stosunku do zmiany środowiska bezpieczeństwa w Azji (chodzi tu m.in. o napięcia pomiędzy Japonią i Chinami i zagrożenie ze strony Korei Północnej). Oczywistym jest zatem, że w sytuacji realnego zagrożenia największy przydział środków kierowany jest na obronę kraju. Może to jednak rzutować na stabilność sytuacji wewnętrznej - oszczędności często dotyczą najbardziej bezbronnych grup społecznych: osób starszych i dzieci. Więcej na temat budżetu: Biggest Defense Budget Requests (2014), „The Japan Times”, http://www.japantimes.co.jp/ opinion/2014/09/05/editorials/biggest-defense-budget-requests/\#.VHdX6vmG9Z8 (4.12.2014). 
w obszarach mniej zurbanizowanych stale się kurczą (Lützeler, 2008: 70-71). Innymi słowy zjawisko depopulacji oznacza zahamowanie wzrostu gospodarczego i obciążenie dla finansów publicznych w obszarach wiejskich. Jest to spowodowane brakiem osób w wieku produkcyjnym i niskim współczynnikiem urodzeń. Na migrację należy spojrzeć również z drugiej strony - jeżeli na obszarach wiejskich występuje depopulacja, to migranci kierują się do obszarów zurbanizowanych, które i tak są już przeludnione. Mimo że ogólny spadek liczby ludności będzie w niedalekiej perspektywie dotyczył również dużych miast, to nawet tu coraz więcej mieszkańców znajdujących się w zaawansowanym wieku będzie wymagało dużych nakładów finansowych na odpowiednią opiekę społeczną. Przeludnienie $\mathrm{w}$ dużych miastach niesie za sobą również zagrożenie militarne. Jak pisze J. Sciubba, ,to, co czyni miasta atrakcyjnym z ekonomicznego punktu widzenia - koncentracja ludności, biznesu i władzy - czyni je również atrakcyjnym pod względem militarnym. Miasto staje się celem" (Sciubba, 2011: 113). Ponadto, w Japonii mówi się również o skutkach katastrof naturalnych, które w dużych metropoliach są najbardziej druzgocące - chodzi tu oczywiście o liczbę poszkodowanych osób, ale również o skutki ekonomiczne. Zniszczenia, na jakie narażona jest rozbudowana infrastruktura, niosą za sobą poważne konsekwencje dla komunikacji, inwestycji i handlu. Przykładowo - szacuje się, że trzęsienie ziemi w Kobe kosztowało Japonię ponad 100 miliardów dolarów (Mitchell, 1999: 137), a trzęsienie ziemi w regionie Tōhoku w 2011 - ponad 200 miliardów ${ }^{15}$ („Reuters”, 2011).

\section{$* * *$}

Analiza problemów demograficznych Japonii pozwala na określenie w jaki sposób zmiany w strukturze populacji stwarzają wyzwania dla bezpieczeństwa kraju. Mimo że niniejsze analizy dotyczą jedynie negatywnych aspektów starzenia się społeczeństwa i niskiego współczynnika urodzeń, nie sposób mówić o zmianach demograficznych tylko z perspektywy negatywnych konsekwencji. Jak podkreśla wielu badaczy, społeczeństwo o liczebnej grupie wiekowej osób starszych może mieć również pozytywne skutki - przykładowo, państwa są dzięki temu mniej podatne na konflikt cywilny (Sciubba, 2011: 17-38). Demografowie zapowiadają nawet tzw. ,pokój demograficzny” (ang. demographic peace) lub „pokój geriatryczny” (ang. geriatric peace), czyli globalne starzenie się społeczeństwa, w którym państwa o wysokiej średniej wieku będą dążyć raczej do stabilizacji niż do konfliktu. Ponadto niektórzy ekonomiści wierza, że japoński cud ekonomiczny lat 60 . był możliwy właśnie dzięki zmniejszaniu się współczynnika dzietności uzasadniając, że mniejszy przyrost ludności i mniej środków przeznaczanych na dzieci wygenerowały spory potencjał inwestycyjny i pozwoliły na zrównoważony rozwój infrastruktury i przemysłu (Sylva, Yoshihara, 2011: 24-25). Mimo to zachodzące w Japonii zmiany demograficzne i ich prognostyka nie napawają optymizmem. Spadek liczebności populacji jest ważnym elementem wyznaczającym rozkład sił w skali globalnej - efekty zmian demograficznych wpływają bowiem na strategię państwa, politykę zagraniczną i klimat polityczny (ibidem: 60). Jak

15 Nie licząc kosztów spowodowanej trzęsieniem ziemi katastrofy nuklearnej w Fukushimie, które stale rosną z powodu nadal trwających prac porządkowych. 
omówiono w niniejszej pracy, demografia może napędzać lub spowalniać gospodarkę. Stan gospodarki zmienia natomiast rozkład sił globalnych. To z kolei doprowadza do destabilizacji - zmian w postawach strategicznych oraz zacieśniania lub rozluźniania sojuszy pomiędzy państwami. Skutki takiej destabilizacji odczuła już Japonia, która straciła pozycję drugiej światowej potęgi gospodarczej na rzecz ChRL w 2010 r. Od tego czasu rząd Japonii - wbrew kondycji ekonomicznej kraju oraz mimo topniejących zasobów ludzkich i militarnych - dokłada wszelkich starań, aby podtrzymać i umocnić wizerunek kraju jako partnera globalnego. S. Yoshihara pisze o dysharmonii pomiędzy dyplomacją, strategią i zasobami, jakimi Japonia dysponuje (ibidem: 153). Nie bez znaczenia jest również badanie japońskich trendów demograficznych w świetle sytuacji Europy, w tym Polski. Mimo że nie tak drastyczne jak w Japonii, zjawiska starzejącego się społeczeństwa i niskiego współczynnika urodzeń dotyczą również większości państw Unii Europejskiej. Prognozuje się, że jeżeli współczynnik urodzeń utrzyma się na obecnym poziomie, co jest dość optymistycznym scenariuszem, to w 2050 r. populacja europejska skurczy się o 67 milionów ludzi (Sylva, Yoshihara, 2011: 96). Trwające już od kilkudziesięciu lat zmagania Japonii z efektami starzejącego się społeczeństwa są przestrogą i jednocześnie inspiracją. Obecna sytuacja Japonii pokazuje bowiem, że zmiany demograficzne stanowią nie tylko hamulec dla powiększania PKB i problem wypłacalności krajów na finansowanie opieki społecznej. Jest to również ogromne wyzwanie strategiczne, wpływające na problem bezpieczeństwa i sytuacji państwa w środowisku międzynarodowym.

\section{Bibliografia}

Asian Development Bank (2013), Partnering for development donor report, Manila.

Atanassova-Cornelis E. (2010), Dynamics of Japanese and Chinese security Policies In East Asia and Implications for Regional Stability, „Asian Politics \& Policy”, Vol. 2, No. 3. DOI: 10.1111/j.1943-0787.2010.01200.x.

Baby boom sets Japan '2007 problem', http://news.bbc.co.uk/2/hi/asia-pacific/5263514.stm (4.12.2014).

Biggest Defense Budget Requests (2014), http://www.japantimes.co.jp/opinion/2014/09/05/editorials/biggest-defense-budget-requests/\#.VHdX6vmG9Z8 (4.12.2014).

Chwiej E. (2013), The Influence of Demographic Processes on the Security of the Selected Asian States, w: Dilemmas of Contemporary Asia. Deliberations on Economy and Security, (ed.) J. Marszałek-Kawa, Toruń.

Demography is Destiny (2012), http://www.weeklystandard.com/articles/demography-destiny_636998.html?page $=1(30.11 .2014)$.

French military heads threaten to resign over 'grave' defence cuts (2014), http://www.telegraph.co.uk/news/worldnews/europe/france/10852165/French-military-heads-threaten-to-resign-over-grave-defence-cuts.html (5.12.2014).

Gaimushō [Ministerstwo Spraw Zagranicznych] (2014), Japan's Contribution to UN Peacekeeping Operations.

Has Britain’s Defence Budget Has been Cut Too Much? (2014), http://www.bbc.com/news/uk-26271018 (5.12.2014) 
Hashimoto M. (1974), Economics of Postwar Fertility in Japan, w: Economics of the Family: Marriage, Children, and Human Capital, (ed.) T. W. Schultz, Chicago, DOI: 10.1086/260299.

Holzer J. (2003), Demografia, Warszawa.

In Abenomics' shadow, Japanese women fight 'maternity harassment' (2014), http://uk.reuters.com/article/2014/09/24/us-japan-women-idUKKCN0HJ2BA20140924 (5.12.2014).

International Longevity Center Japan (b.d.w.), Regional Issues, and Local Government Measures: Making It Possible to Continue Living in a Familiar Environment with a Sense of Security, http://longevity.ilcjapan.org/f_issues/0610.html (4.12.2014).

International Monetary Fund (2014), IMF Members' Quotas and Voting Power, and IMF Board of Governors.

Japan again seeks permanent UNSC seat; China the biggest hurdle (2014), http://ajw.asahi.com/article/behind_news/politics/AJ201409260068 (5.12.2014).

Katsuno M. (2012), Japan's Quest for a Permament Seat, http://library.fes.de/pdf-files/id/09024.pdf (4.12.2014).

Kawase A., Ogura S. (2008), Macroeconomic impact and Public Finance Perspectives of the Ageing Society, w: The demographic challenge: A handbook about Japan, (eds.) F. Coulmas, H. Conrad, A. Schad-Seifert, G. Vogt, Boston, DOI: 10.1163/ej.9789004154773.i-1199.346.

Kingston J. (2011), Contemporary Japan: History, Politics, and Social Change since the 1980s, Oxford, DOI: 10.5860/choice.48-3425.

Kōsei rōdōshō [Ministerstwo Zdrowia, Pracy i Opieki Społecznej] (2011), Heisei 23 nen jinkō dōtai sōkei geppō toshikei (gaisū) gaikyō [Sytuacja ogólna zmiany (szacowanej) liczby populacji $\mathrm{z}$ podziałem na lata].

Leuprecht C. (2010), International Security Strategy and Global Population Aging, ,Journal of Strategic Security”, Vol. 3, No. 4, DOI: 10.5038/1944-0472.3.4.2.

Lützeler R. (2008), Regional demographics, w: The demographic challenge: A handbook about Japan, (eds.) F. Coulmas, H. Conrad, A. Schad-Seifert, G. Vogt, Boston, DOI: 10.1163/ej.9789004154773.i-1199.33.

Maternity leave, day care still elude many working mothers (2014), http://www.japantimes.co.jp/ news/2013/06/18/national/social-issues/maternity-leave-day-care-still-elude/\#.VHYCuPmG9Z8 (5.12.2014).

Matsukura R., Retherford R. D., Ogawa N. (2007), Declining Fertility in Japan: Its Mechanisms and Policy Responses, „Asia-Pacific Population Journal”, Vol. 22, No. 2, DOI: 10.1007/bf03031797.

Mitchell J. K. (1999), Megacities and natural disasters: a comparative analysis, „GeoJournal”, Vol. 49.

Official Statistics of Japan (2011), Japan in figures and graphs, http://e-stat.go.jp/SG1/estat/ GL36010101.do?_toGL36010101_(4.12.2014).

Ogawa N. (2008), Population Ageing and Economic Growth: The Role of Two Demographic Dividends in Japan, w: The demographic challenge: A handbook about Japan, (eds.) F. Coulmas, H. Conrad, A. Schad-Seifert, G. Vogt, Boston, DOI: 10.1163/ej.9789004154773.i-1199.340.

Retherford R. D. Ogawa N. (2005), Japan's Baby Bust: Causes, Implications, and Policy Responses, „East-West Center Working Papers”, No. 118.

Shusshōritsu 1,43 ninen renzoku bizō. Sakunen, 30-40 dai shusshōritsuzō (2014), „Asahi Shimbun” 5.06.2014.

Sōmushō [Ministerstwo Spraw Wewnętrznych i Komunikacji] (2012), Kaso taisaku no genkyō [Stan obecny strategii dla depopulacji]. 
Subbarao K., Raney L. (1995), Social Gains from Female Education: A Cross-National Study, „Economic Development and Cultural Change", Vol. 44, No. 1, DOI: 10.1086/452202.

Terada T., Ong B. (2011), Japan and Management of the Transatlantic Crisis: international Responsen and Domestic Struggles, „Contemporary Politics”, Vol. 17, No. 2, DOI: 10.1080/13569775.2011.565990.

Umitai? Umenai? Dankai junia [Chcą rodzić, ale nie mogą. Pokolenie drugiego wyżu demograficznego], „Asahi Shimbun” 10.06.2005.

United Nations. Departament of Economic and Social Affairs (2012), World Population Prospects: The 2012 Revision.

United Nations, Department of Economic and Social Affairs, Population Division (2012), World Population Prospects: The 2012 Revision.

United Nations, Department of Economic and Social Affairs, Population Division (2013), World Population Ageing 2013.

Usui C. (2008), Ageing Society and the Transformation of Work in the Post-Fordist Economy, w: The demographic challenge: A handbook about Japan, (eds.) F. Coulmas, H. Conrad, A. Schad-Seifert, G. Vogt, Boston, DOI: 10.1163/ej.9789004154773.i-1199.68.

Sciubba J. D. (2011), The Future Faces of War : Population and National Security, Santa Barbara, DOI: $10.1111 / \mathrm{j} .1728-4457.2011 .00424 . x$.

Success of 'Abenomics' hinges on immigration policy (2014), http://www.japantimes.co.jp/news/2014/ 05/18/national/success-abenomics-hinges-immigration-policy/\#.VHYTnPmG9Z8 (5.12.2014).

World Bank (2014), http://data.worldbank.org/indicator/SP.URB.TOTL.IN.ZS (4.12.2014).

World Health Organization (2014), http://apps.who.int/gho/data/node.main.688?lang=en (4.12.2014).

WRAPUP 2-Japan quake's economic impact worse than first feared (2011), http://www.reuters.com/ article/2011/04/12/japan-economy-idUSL3E7FC09220110412 (5.12.2014).

The flight from marriage (2011), http://www.economist.com/node/21526329 (4.12.2014).

Yashiro N. (2008), Economic Factors in the Declining Birth Rate, w: The demographic challenge: A handbook about Japan, (eds.) F. Coulmas, H. Conrad, A. Schad-Seifert, G. Vogt, Boston, DOI: 10.1163/ej.9789004154773.i-1199.387.

Yoshihara S., Sylva D. A. (2011), Population Decline and the Remaking of Great Power Politics, Washington, DOI: 10.5840/ncbq201414321.

\title{
STRESZCZENIE
}

Artykuł analizuje wpływ zmian demograficznych na bezpieczeństwo państwa na przykładzie Japonii. Głównym celem jest wyszczególnienie najbardziej znaczących rodzajów zmian demograficznych, w tym przypadku zjawiska starzejącego się społeczeństwa, niskiego współczynnika dzietności oraz migracji wewnętrznych oraz ich analizę w kontekście wpływu na bezpieczeństwo ekonomiczne i militarne Japonii w obecnym środowisku międzynarodowym.

\section{DEMOGRAPHIC CHANGES AS A THREAT TO SECURITY. ANALYSIS ON THE EXAMPLE OF JAPAN}

\begin{abstract}
The article analyses the impact of demographic changes on the national security based on the Japan's experience. The main goal of the article is to highlight the most significant types of de-
\end{abstract}


mographic changes, in this case the aging society, low total fertility rate and domestic migration, and their impact on the Japan's economic and military security in the current international environment. 